\title{
Exploration of Innovation and Entrepreneurship Education Model in Higher Vocational Colleges based on Rural Revitalization Strategy
}

\author{
Guohui $\mathrm{Su}^{*}$ \\ ${ }^{1}$ Guangdong Mechanical and Electrical Polytechnic, Guangzhou 510515, China; \\ ${ }^{2}$ University Of Chinese Academy of Social Sciences, Beijing 102488, China;
}

\begin{abstract}
The outbreak of the COVID-19 epidemic has had a great impact on economic and social development, the task of poverty alleviation has become more difficult, and the strategy of rural revitalization is facing greater challenges. Higher vocational colleges undertake the important mission of training and conveying advanced skilled talents needed for the country's economic and social development, and are bound to assume their own responsibilities in the strategy of rural revitalization. The innovation and entrepreneurship education for college students promoted by higher vocational colleges in recent years provides a feasible implementation path for higher vocational colleges to participate in the country's rural revitalization strategy. Based on the background of the national rural revitalization strategy, this paper points out the great significance of the integration of innovation and entrepreneurship education in higher vocational colleges into the rural revitalization strategy, and puts forward specific measures to realize the integration of innovation and entrepreneurship education into the rural revitalization strategy.

Keywords: Rural Revitalization, Innovation and Entrepreneurship, Integration, Model
\end{abstract}

\section{Introduction}

The proposal of the rural revitalization strategy is a major strategic arrangement and deployment made by the party and the state on the basis of focusing on the overall situation of the cause of socialism with Chinese characteristics and conforming to the people's yearning for a better life in the countryside. It is the grand goal of our country to win a decisive victory and build a moderately prosperous society in an all-round way, as well as a major historical task of building a modern socialist power. It is also an important measure to do a good job in the work of agriculture, rural areas and farmers in the new era.

Higher vocational colleges undertake the task of training and conveying advanced skilled talents needed for the country's economic and social development, and must fulfill the educational mission of higher vocational colleges in the national strategy of agricultural modernization and rural revitalization.

\footnotetext{
* Corresponding author: 506602681@qqq.com
} 
In recent years, higher vocational colleges carry out and promote innovative and entrepreneurial education for college students, attach importance to the reform and innovation of traditional educational methods and methods, and pay attention to the cultivation of students' innovative quality and entrepreneurial skills. especially with the extensive development of Internet + Innovation and Entrepreneurship Competition for Chinese college students, the "Youth Red Dream Tour" has been implemented.

It combines the innovation and entrepreneurship education of colleges and universities with the national rural revitalization strategy more closely.It provides a feasible implementation path for higher vocational colleges to participate in the national rural revitalization strategy through innovative entrepreneurship education.

\section{The great significance of the integration of innovation and entrepreneurship education in higher vocational colleges into the strategy of rural revitalization}

With its unique way of running a school and clear objectives of personnel training, higher vocational colleges can accurately train advanced technical and skilled talents with all-round development of morality, intelligence, physique, beauty and labor for rural revitalization, by promoting innovative entrepreneurship education, better integration into the country's rural revitalization strategy is undoubtedly of great significance.

\subsection{Promoting rural economic and social development}

At the beginning of 2020, in the face of the surging COVID-19 epidemic, the CPC Central Committee led the people of the whole country to carry out an arduous fight against the epidemic, and the prevention and control of the epidemic achieved phased victories, ensuring the safety and health of the people; but to this end, China has also made a huge price, the economy and society are deeply affected by the epidemic, the task of poverty alleviation is more difficult, and the strategy of rural revitalization is facing greater challenges[1].

To carry out innovative and entrepreneurial education, mobilize teachers and students to participate in rural revitalization, develop rural e-commerce, and implement "Internet + agriculture" are of great significance in promoting rural economic and social development, solving the employment of rural labor force, and smoothly realizing the task of poverty alleviation and tackling key problems, and implementing the strategy of rural revitalization.

Driven by innovation and entrepreneurship education, we can not only solve the circulation problems of agricultural products, but also form channels conducive to expanding the market sales of agricultural products, so that farmers are no longer confused, so that agricultural products "have a place to go". It is easy to reduce the production risk of agricultural products, solve the problems of information asymmetry in the trading process of agricultural products, and solve the problems of smooth information flow of agricultural products in the market.

\subsection{Improving the quality of running higher vocational colleges}

In the new era, the development task faced by higher vocational colleges is more arduous. in the face of the task of high-level vocational colleges and high-level professional construction with Chinese characteristics, how to ensure the socialist school-running direction of the school? reflect the goal of the party and the state for vocational education, and effectively provide the necessary talents for economic and social development. In the coming 14th fiveyear Plan, more higher vocational colleges will enter the undergraduate school-running level. 
Higher vocational colleges must make use of the rare opportunity of integrating innovation and entrepreneurship education into the rural rejuvenation to realize their own development and contribute to the great rejuvenation of the Chinese nation.

On the basis of running higher vocational colleges, we will continue to expand and extend the social service function through the strategy of rural revitalization, which will provide new driving force and support for the professional construction and personnel training of higher vocational colleges.

With the in-depth implementation of the rural revitalization strategy, especially under the background of the large-scale application of $5 \mathrm{G}$ technology, higher vocational colleges must speed up the mastery and application of new technologies and more actively serve the national development strategy [2]. Only by integrating the development and application of new technologies and new industries with innovative entrepreneurship education as a starting point, can professional construction be more dynamic and effective.

So as to further improve the school-running level and talent training ability of higher vocational colleges, and earnestly undertake the social responsibility of high-level higher vocational colleges with Chinese characteristics.

\section{Opportunities and challenges of Innovation and Entrepreneurship in higher vocational colleges to serve rural revitalization strategy}

Since 2020, COVID-19 has wreaked havoc, and the task of getting rid of poverty is arduous, and the strategic significance of rural revitalization is even more important. as the final year of the 13th five-year Plan, there are good opportunities for innovative entrepreneurial services in higher vocational colleges and the country's rural revitalization strategy. at the same time, it faces severe challenges.

\subsection{The opportunities faced by college students in the process of connecting with the countryside through innovation and entrepreneurship}

Standing in the historical period of the intersection of two century-old dreams, accurate poverty alleviation and rural revitalization are both important strategic arrangements of the CPC Central Committee and the solemn commitment of the Chinese Government to the people. Continuing to maintain vitality and creativity in the countryside has become the key to promoting rural revitalization, and college students are an important force to create vitality for rural development.

First of all, the release of preferential policies related to rural development and college students' innovation and entrepreneurship provides them with important opportunities. For example, in February 2019, the "opinions on the implementation of Agricultural and Rural work in 2019" issued by the Ministry of Agriculture and villages of the people's Republic of China clearly put forward the implementation of the "digital countryside" strategy and strengthening the innovation and promotion of agricultural science and technology. actively promote agriculture to go out, and the "opinions on further promoting the work of returning to hometown and starting a business" have further promoted the innovation and entrepreneurship of college students to connect with the countryside. Secondly, the arrival of 5G makes the Internet show more charm [3]. The mode of combining rural economic development with network science and technology can not only promote the effective integration of rural resources and improve the utilization rate of rural resources, but also provide a broad development space for college students to innovate and start their own businesses. Finally, the continuous enhancement of college students' awareness of innovation 
and entrepreneurship, and the continuous improvement of the school innovation and entrepreneurship platform, promote college students to actively move closer to the countryside in the process of innovation and entrepreneurship, provide more talents for the countryside, and promote the integration and development of rural industries.

\subsection{The challenges faced by the students of higher Vocational Colleges in the process of connecting the Countryside with Innovation and Entrepreneurship}

At present, although many students in higher vocational colleges have a strong enthusiasm for innovation and entrepreneurship, they can actively respond to the national call and strive to go deep into the grass-roots level, into the countryside and develop agriculture, but it is undeniable that most of the innovative and entrepreneurial projects of students in higher vocational colleges still remain at the creative level [4].

At the present stage, the bottleneck of natural resources appears in some rural areas and communities, which leads to the lack of corresponding innovative and entrepreneurial resources for students in higher vocational colleges when docking with the countryside; at the same time, the shortage of venture capital has become another obstacle for college students in the process of serving the countryside.

In addition to the obstacles brought by the rural areas, college students also have their own reasons for the problems existing in the service of rural revitalization in higher vocational colleges in recent years.

First of all, many college students do not have a deep understanding of the country's rural revitalization policy, and higher vocational college students are at an ambiguous stage of rural and community development and goal orientation. not to mention the work deployment of the national rural revitalization strategy and the characteristic policies of the corresponding areas [5]; secondly, the lack of social practice experience of higher vocational college students makes them at a disadvantage in raising resources and opening up markets [6]. Finally, due to the differences in ideas and considerations for their own future, the willingness of college students to go to the countryside is relatively low, which makes the countryside lack of corresponding human resources in the process of its development [7].

\section{The concrete measures to realize the integration of innovation and entrepreneurship education into the strategy of rural revitalization}

Innovation and entrepreneurship education focuses on the reform and innovation of talent training methods, and aims to serve the country's development strategy by breaking through the existing technology and mode of thinking. to realize the integration of innovation and entrepreneurship education into the rural revitalization strategy of serving the country should start from the following three directions.

\subsection{To establish the family and national feelings of teachers and students in higher vocational colleges through innovative entrepreneurship education}

The implementation of the rural revitalization strategy has a strong nature of the times. The education of innovation and entrepreneurship in higher vocational colleges will guide teachers and students to fully understand the country's rural revitalization development strategy and take root in the countryside. we should conscientiously carry out demand research, analyze the characteristics of rural agricultural products, understand the key points and difficulties of rural revitalization, pay attention to education and guide students to carry 
forward the spirit of labor, and combine "reading ten thousand books" with "traveling ten thousand miles".

Take root in China to understand the national conditions and people's conditions, increase wisdom and talent in practice, and temper will and character in the course of hard struggle.

At the same time, in the process of carrying out innovative and entrepreneurial projects, it can improve the scientific thinking methods of teachers and students, cultivate students' sense of responsibility and mission to explore the unknown, pursue the truth, and courageously scale the peak of science and technology. stimulate the team members' feelings of home and country and mission to serve the country with science and technology.

\subsection{To guide teachers and students to promote the integration of new cross- disciplines in the process of innovation and entrepreneurship}

As far as the specialty setting of higher vocational colleges is concerned, there are many professional fields related to rural revitalization, such as the theory of party building, grassroots governance and other sociological fields, as well as VR, AR, Internet of things and other technologies extended by $5 \mathrm{G}$ new technology, as well as network technology, Web browsing technology, security technology, database technology, electronic payment technology, network data communication technology and other key technologies needed by e-commerce.

The application of new technologies will speed up the further integration of crossdisciplines, provide a good foundation for scientific and technological innovation, and enable the team members involved to better master and use these new technologies in the process of practice. cultivate the combination of science and education to cultivate innovative talents. The team of innovative and entrepreneurial teachers and students who participate in rural revitalization should pay attention to strengthening the mastery and integration of new technologies in this process.

The team of innovative and entrepreneurial teachers and students who participate in rural revitalization should pay attention to strengthening the mastery and integration of new technologies in this process [8].

\subsection{Give full play to the application and popularization of $5 G$ and other new technologies, and promote the integration of college students' innovation and entrepreneurship education into rural revitalization.}

Under the background of the rapid popularization and development of the Internet, the state has issued many policies to promote the coverage of rural e-commerce, and the "Government work report" proposes to implement the "Internet +" action plan. Among them, "Internet + Agriculture" is an important part of the plan.

E-commerce has become an indispensable means to implement the rural revitalization strategy. The "implementation Plan of Guangdong Province for promoting the Development of Rural E-commerce" released in 2016 mentions "vigorously supporting the construction of local e-commerce platforms for the management of famous agricultural products, agricultural products and rural tourism cultural products in the province".

E-commerce has come into people's field of vision, but also plays a more and more important role in people's lives, and has attracted the attention of many consumers.

The extensive use of $5 \mathrm{G}$ technology will also promote the further integration of innovation and entrepreneurship education and rural revitalization strategy.

From the perspective of the application of $5 \mathrm{G}$ technology, the research on the construction of rural e-commerce platform has strong innovation and practicability, and is of great 
significance for rural e-commerce how to serve the revitalization of rural areas. it has great potential for the integration and development of cross-fusion technology.

\section{Acknowledgements}

This work was financially supported by Scientific Research platform and projects of Guangdong Provincial Department of Education in 2020, Research on the Construction of Rural E-commerce platform under the background of 5G Technology (2020ZDZX1076).

\section{References}

1. Y. QU, Inner Mongolia Science Technology \& Economy,457(15),10-11, (2020)

2. W. XU, Reformation \& Strategy,35(5),55-62, (2019)

3. W. LUO, Journal of Wuhan Polytechnic University,39(2),73-79, (2020)

4. C.JIANG, Journal of Research on Education for Ethnic Minorities,31(3),26-30, (2020)

5. Y. ZHONG, Journal of Higher Education,40(8),88-97, (2019)

6. M Xu, H Wei, H Ni, China Higher Education Research,257(1),45-48,(2018)

7. X.LUO, Journal of Jiangsu Ocean University (Humanities \& Social Sciences Edition), 17(6),117-120, (2019)

8. X.WANG, Journal of Architectural Education in Institutions of Higher Learning, 28(6), 164-170, (2019) 